\title{
Relationship between Growth and Wood properties in Agathis sp. Planted in Indonesia
}

\author{
Futoshi Ishiguri, Kazuko Makino, Imam Wahyudi, Jun Tanabe, Yuya Takashima, \\ Kazuya lizuka, Shinso Yokota, and Nobuo Yoshizawa
}

\begin{abstract}
The present study clarified the relationship between the growth and wood properties of 54-year-old Agathis sp. trees planted in Indonesia. Stem diameter, pilodyn penetration, and stress-wave velocity (SWV) were measured for all trees (35 trees) in a plot $(30 \times 30 \mathrm{~m})$ located almost at the center of a stand. Based on the mean stem diameter, 10 standard trees in a plot were selected for measuring the basic density (BD) and compressive strength parallel to grain (CS). Core samples (5 mm in diameter) were collected from the 10 selected trees to determine BD and CS. The mean stem diameter, pilodyn penetration and SWV in the plot were $40.2 \pm 11.3 \mathrm{~cm}, 23.4 \pm 2.1 \mathrm{~cm}$, and $3.85 \pm 0.43 \mathrm{~km} / \mathrm{s}$, respectively. No significant correlation coefficeint ( $r=-0.327$, no significance at $5 \%$ level) was obtained between stem diameter and SWV. The mean BD and CS in the 10 trees were $0.42 \pm 0.03 \mathrm{~g} / \mathrm{cm}^{3}$ and $28.1 \pm 2.7 \mathrm{MPa}$, respectively. A significant positive correlation was observed between BD and CS. Analysis of variance (ANOVA) revealed a significant difference between BD and CS values of the 10 trees, indicating that wood properties may differ among trees with the same standard growth in a stand. From these results, we concluded that wood quality improvement in this species could be achieved by selecting trees with high density and strength in tree breeding programs.
\end{abstract}

Keywords: Agathis sp., stress-wave velocity, pilodyn penetration, compressive strength, basic density.

\section{Introduction}

Agathis spp. is widely distributed throughout Indochina, Malaysia, Indonesia, and the Philippines and extended to New Guinea, New Zealand, and Fiji (Chudnoff 1980). Wood from Agathis spp. is considered to be general purpose softwood, and it is used for construction timber, plywood, furniture, etc (Soerianegara and Lemmens 1994). The inner bark of Agathis spp. exudes a translucent or clear white resin known as "copal" or "Manila copal" (Soerianegara and Lemmens 1994). This resin was previously an important component of varnish and was also used in the manufacture of linoleum (Soerianegara and Lemmens 1994). Thus, these species were considered important plantation trees, because local people living in forests or surrounding areas could harvest "copal" as a non-timber forest product before cutting the tree. Information regarding possible betweentree variation in wood properties in these species is very limited (Wood Technology Division and Forest Products Chemistry Division 1974; Chudnoff 1980; Soerianegara and Lemmens 1994; Ishiguri et al. 2010).

This study measured the stem diameter, stress-wave velocity (SWV), and pilodyn penetration of 54-year-old Agathis sp. trees planted in Indonesia. SWV and pilodyn penetration values are closely related to Young's modulus of stem and wood density, respectively. Moreover, wood properties, such as basic density (BD) and compressive strength parallel to grain (CS), were investigated in plantation-grown Agathis sp. to clarify the relationship between growth and wood properties. Based on the results, we discuss the possibility of improving the wood properties of this species using tree breeding programs.

\section{Materials and Methods}

The experimental Agathis sp. stand was located in Gunung Walat, Educational Forest, Bogor Agricultural University, Sukabumi, Indonesia (6 $\left.6^{\circ} 54^{\prime} \mathrm{S}, 106^{\circ} 49^{\prime} \mathrm{E}\right)$. The stand was established using seedlings in 1956. The seed source was unknown and silviculture management after planting was not recorded. Part of the bark had been removed by local people while harvesting copal. All wood properties were measured in sound areas, complete with the bark. A plot $(30 \times 30 \mathrm{~m})$ was selected in the center of the stand. Stem diameter, SWV, and pilodyn penetration were measured for all trees in the plot (35 trees). The stem diameter was determined at $1.3 \mathrm{~m}$ above the ground level. Stress-wave propagation time was determined at $70 \sim 170$ $\mathrm{cm}$ above the ground using a commercial handheld stresswave timer (Fakopp, Fakopp Enterprise). SWV was determined as the distance between the sensors $(1 \mathrm{~m})$ dividing by the mean values of the stress-wave propagation time calculated from six measurements per stem. Pilodyn penetration, including the bark thickness, was measured at a single position on each stem using a pilodyn tester (strength of spring $=6 \mathrm{~J}$, diameter of pin $=2.5 \mathrm{~mm}$; Proceq).

Based on the mean diameter in the plot, 10 trees exhibiting standard growth were selected to determine their wood properties (BD and CS). Two core samples (5 $\mathrm{mm}$ in diameter) extending from the pith to the bark were collected at $1.3 \mathrm{~m}$ above the ground height from each selected tree and used to measure the wood properties. BD was 
determined at $1 \mathrm{~cm}$ intervals from the pith to the bark based on the oven-dried weight divided by the green volume measured by water displacement. CS was measured at 5$\mathrm{mm}$ intervals from the pith to the bark by using a core sample testing machine (Fractometer II, IML). CS values obtained with core sample using this equipment had almost the same CS values as those obtained using a compressive test with small clear specimens $(20(\mathrm{R}) \times 20(\mathrm{~T}) \times 60(\mathrm{~L})$ $\mathrm{mm}$ ) according to the Japan Industrial Standard (JIS) (Matsumoto et al. 2008). Mean values from the pith to the bark were calculated at 2-cm intervals to determine any radial variation in the wood properties.

\section{Results and Discussion}

\section{SWV and Pilodyn Penetration}

The mean stem diameter at $1.3 \mathrm{~m}$ above the ground, pilodyn penetration, and SWV of trees were $40.2 \mathrm{~cm}, 23.4$ $\mathrm{mm}$, and $3.85 \mathrm{~km} / \mathrm{s}$, respectively (Table 1). Previous studies report no correlation or a weak negative correlation between the stem diameter and SWV of softwood species (Ikeda and Arima 2000; Chauhan and Walker 2006; Ishiguri et al. 2008). Chauhan and Walker (2006) reported a weak negative correlation between the stem diameter and SWV in 8-, 16-, and 25-year-old Pinus radiata D. Don. Figure 1 shows that there was a negative but insignificant correlation between stem diameter and SWV in the present study. The stem SWV is closely related to Young's modulus of logs (Ikeda and Arima 2000; Ishiguri et al. 2008). Thus, Young's modulus of stems may be independent of growth diameter in this species. Mean pilodyn penetration has been shown to be closely related with wood density (Taylor 1981; Ishiguri et al. 2006; Iki et al. 2009). Iki et al. (2009) reported a significant negative correlation between the mean $\mathrm{BD}$ and pilodyn penetration value in 18 trees derived from 7 clones of 43-year-old Abies sachalinensis Masters. However, we found no significant correlation coefficient $(r=-0.256$, no significance at $5 \%$ level) between pilodyn penetration and mean BD (Table 2). Ishiguri et al. (2006) found a significant negative correlation between pilodyn penetration and $\mathrm{BD}$ in the outermost parts of Chamaecyparis obtusa Endl. We determined the correlation for each $\mathrm{BD}$ value at different distances from the bark and a significant negative correlation coefficient ( $r=-0.654$, significance at $5 \%$ level) was obtained between the pilodyn penetration and $\mathrm{BD}$ at 2 $\mathrm{cm}$ from the bark (Table 2). Thus, the density close to the bark could be predicted from the pilodyn penetration value.

\section{Basic Density and Compressive Strength}

The mean $\mathrm{BD}$ and $\mathrm{CS}$ in the 10 selected trees were $0.42 \pm 0.03 \mathrm{~g} / \mathrm{cm}^{3}$ and $28.1 \pm 2.7 \mathrm{MPa}$, respectively (Table 3). Chudnoff (1980) reported that BD in Agathis sp. ranged from 0.41 to $0.47 \mathrm{~g} / \mathrm{cm}^{3}$. The minimum, maximum, and mean BD in Agathis sp. harvested from Kalimantan were $0.35,0.40$, and $0.37 \mathrm{~g} / \mathrm{cm}^{3}$, respectively (Wood Technology Division and Forest Products Chemistry Division 1974).
Ishiguri et al. (2010) showed that the mean BD in a 45-yearold Agathis sp. tree was $0.35 \mathrm{~g} / \mathrm{cm}^{3}$. Chudnoff (1980) also reported that CS in a green condition ranged from 19.6 to $27.9 \mathrm{MPa}$. Thus, BD and CS results achieved in the present study were similar to those reported by Chudnoff (1980).

Table 1. Mean values of stem diameter, pilodyn penetration, and stress-wave velocity of trees in a plot.

\begin{tabular}{cccc}
\hline & $\begin{array}{c}\text { Stem } \\
\text { diameter } \\
(\mathrm{cm})\end{array}$ & $\begin{array}{c}\text { Pilodyn } \\
\text { penetration } \\
(\mathrm{mm})\end{array}$ & $\begin{array}{c}\text { Stress-wave } \\
\text { velocity }(\mathrm{km} / \mathrm{s})\end{array}$ \\
\hline Minimum & 21.9 & 19.0 & 2.95 \\
Mean & 40.2 & 23.4 & 3.85 \\
Maximum & 68.5 & 28.0 & 4.84 \\
SD & 11.3 & 2.1 & 0.43 \\
\hline
\end{tabular}

Note: number of trees $=35$.
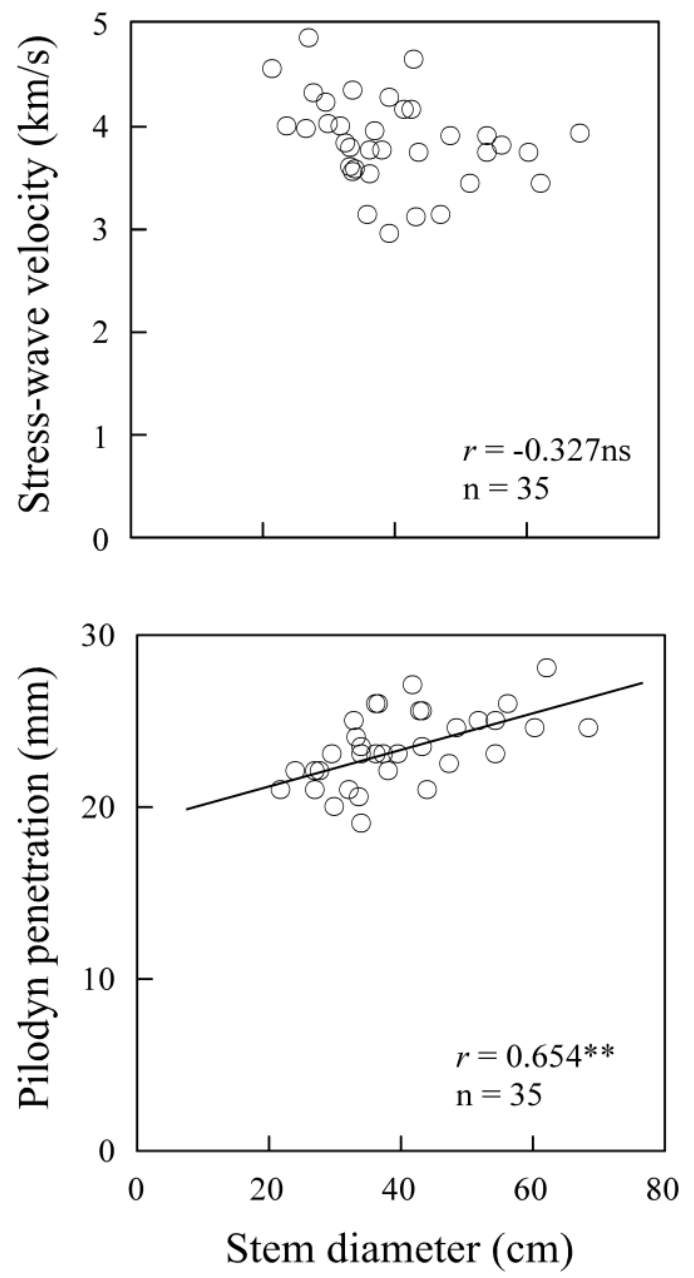

Figure 1. Relationships between the stem diameter and stress-wave velocity or pilodyn penetration of the selected trees in the plot.

Note: $\quad r$, correlation coefficient; $n$, number of trees; ${ }^{*}$, significance at $1 \%$ level; ns, no significance. 
Table 2. Correlation coefficients for pilodyn penetration and basic density.

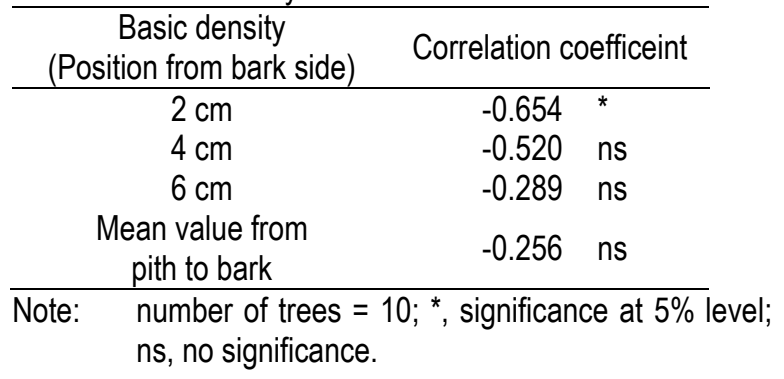

Figure 2 shows the radial variation of the mean $\mathrm{BD}$ and CS from 10 selected trees. BD and CS gradually decreased nearer to the bark. Ishiguri et al. (2010) reported that BD in 45-year-old Agathis sp. was almost constant from the pith to the bark. In Agathis sp. harvested from Kalimantan BD gradually decreased toward the bark. Thus, a constant BD from the pith to the bark or a gradual decrease toward the bark might be the typical radial profile of Agathis sp. In contrast, CS is known to be closely related to density (Kollman and Côté 1984). Figure 3 shows that a significant positive correlation was observed $(r=0.814,1 \%$ level) between CS and BD in the 10 selected trees. Thus, the gradual decrease in CS toward the bark was correlated with the decrease in $\mathrm{BD}$ near the bark.
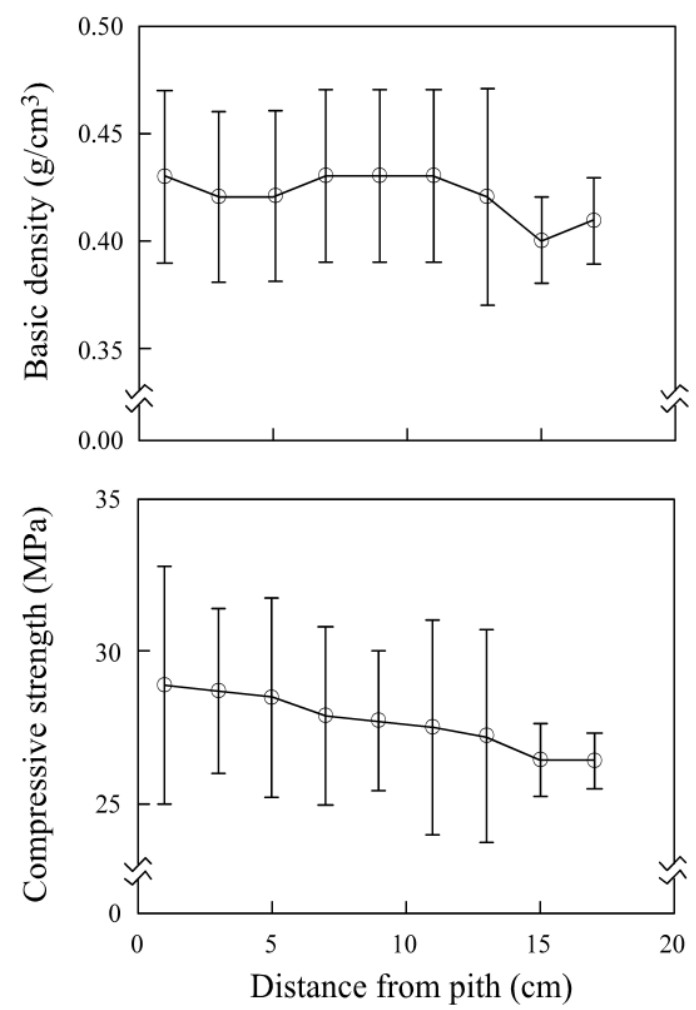

Figure 2. Radial variation in the basic density and compressive strength parallel to the grain.

Note: Circles and bars indicate mean and standard deviation of the 10 selected sample trees.

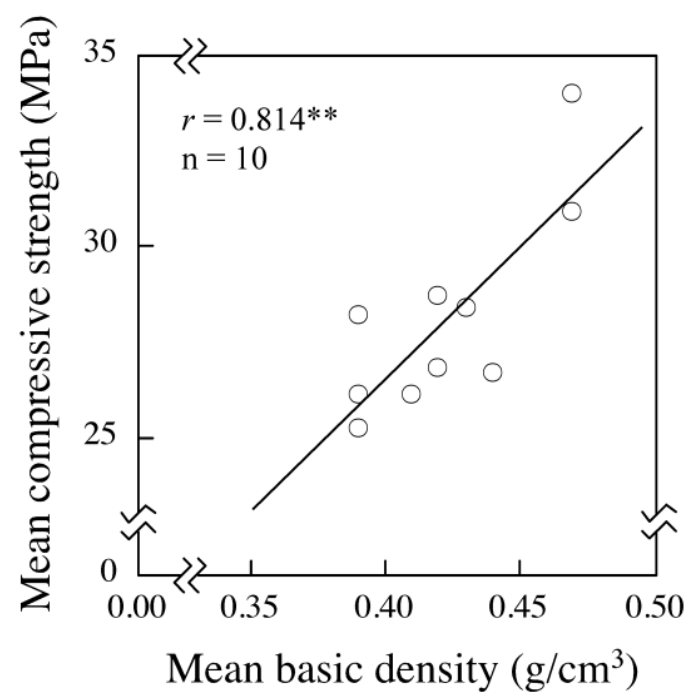

Figure 3. Relationship between the basic density and compressive strength parallel to the grain.

Note: $r$, correlation coefficient; $n$, number of trees; **, significance at $1 \%$ level; Circles indicate mean values for each sample tree.

The correlation coefficient for each position at 2, 4, and $6 \mathrm{~cm}$ from the pith and 2, 4, and $6 \mathrm{~cm}$ from the bark, respectively, were determined to evaluate the possibility of the early selection of wood with high density and strength (Table 4). Significant positive correlations were found for BD between a position $6 \mathrm{~cm}$ from the pith and $6 \mathrm{~cm}$ from the bark, and for $\mathrm{CS}$ between positions 4 and $6 \mathrm{~cm}$ from the pith and 4 and $6 \mathrm{~cm}$ from the bark, respectively. If trees grow evenly each year, the mean annual increment in the half radius can be calculated using the following equation:

\section{Mean annual increment in half radius $(\mathrm{cm} / \mathrm{year})=(D / 2) / A$}

where, $D$ is the mean diameter of the plot $(\mathrm{cm})$ and $A$ is the stand age (year). As previously noted, the mean diameter and stand age were $40.2 \mathrm{~cm}$ and 54 years in the present study. Thus, the mean annual increment in the half radius was $0.37 \mathrm{~cm} /$ year. Based on these results, a tree with a half radius of $6 \mathrm{~cm}$ would be produced 16 years after planting ( 6 $\mathrm{cm} / 0.37 \mathrm{~cm}$ per year). Thus, selecting trees with high density and strength properties may be possible 16 years after planting.

Figure 4 shows no significant correlation was observed between the stem diameter and wood properties in the 10 trees selected in this study. However, significant differences were observed in $\mathrm{BD}$ and $\mathrm{CS}$ among the 10 trees by analysis of variance (ANOVA) (Table 3). Thus, the wood properties of Agathis sp. may not depend on growth characteristics such as radial growth. The 10 standard sized trees also exhibited different wood properties. It is concluded that wood quality improvement in this species could be achieved by selecting trees with high density and strength in tree breeding programs. 
Table 3. Mean values of wood properties for the 10 selected sample trees.

\begin{tabular}{lccccc}
\hline & $\begin{array}{c}\text { Stem } \\
\text { diameter } \\
(\mathrm{cm})\end{array}$ & $\begin{array}{c}\text { Pilodyn } \\
\text { penetration } \\
(\mathrm{mm})\end{array}$ & $\begin{array}{c}\text { Stress-wave } \\
\text { velocity }(\mathrm{km} / \mathrm{s})\end{array}$ & $\begin{array}{c}\text { Basic density } \\
\left(\mathrm{g} / \mathrm{cm}^{3}\right)\end{array}$ & $\begin{array}{c}\text { Compressive } \\
\text { strength }(\mathrm{MPa})\end{array}$ \\
\hline Minimum & 30.1 & 19.0 & 3.54 & 0.39 & 25.2 \\
Mean & 35.0 & 22.1 & 3.83 & 0.42 & 28.1 \\
Maximum & 44.0 & 26.0 & 4.33 & 0.47 & 34.0 \\
SD & 3.9 & 2.2 & 0.23 & 0.03 & 2.7 \\
\hline Significance among & - & - & - & $*$ & $*$ \\
10 trees & - & & & & $*$ \\
\hline
\end{tabular}

Note: SD, standard deviation; -, ANOVA test was not conducted; ${ }^{* *}$, significance at $1 \%$ level.
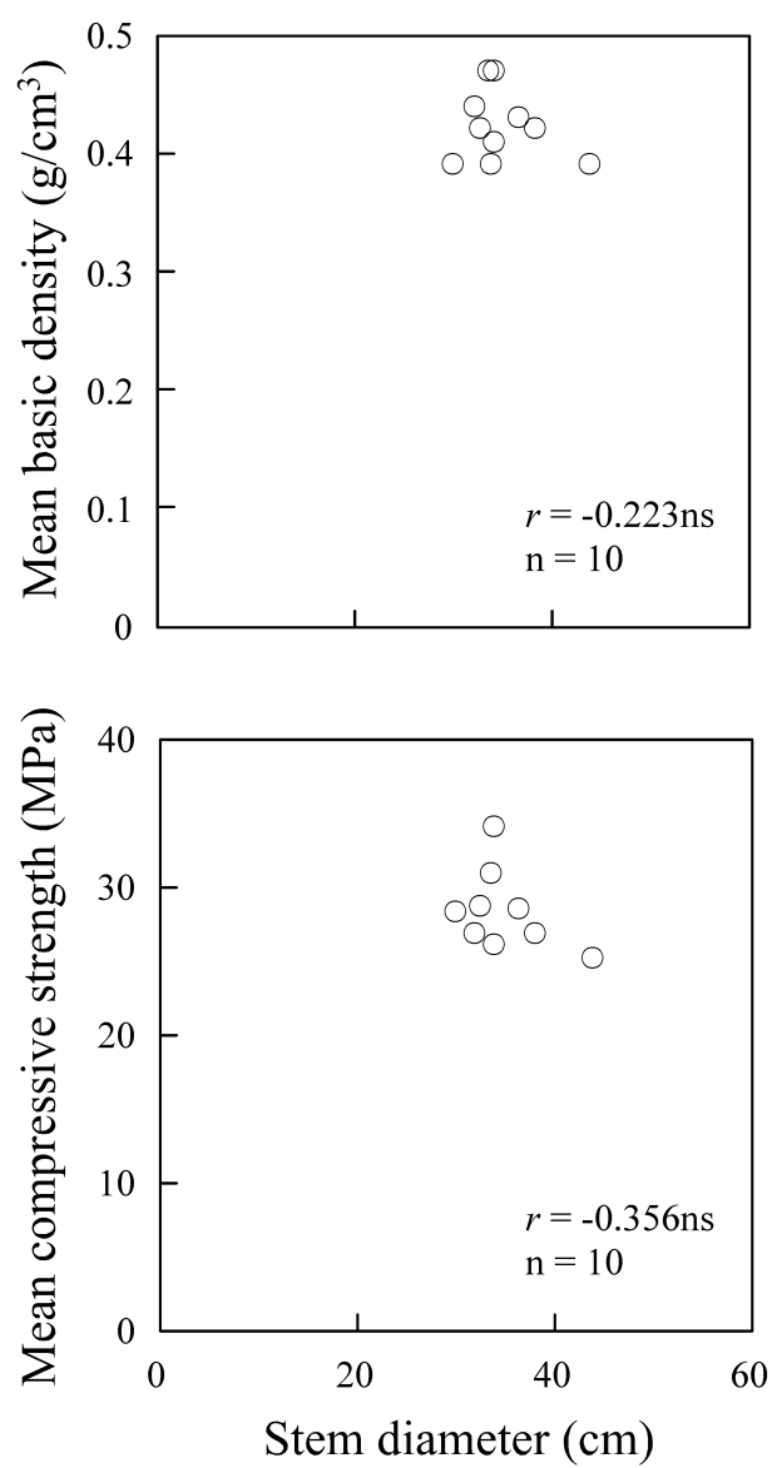

Figure 4. Relationship between the stem diameter and mean basic density or mean compressive strength parallel to the grain for the 10 selected sample trees.

Note: r, correlation coefficient; $n$, number of trees; $n s$, no significance. Circles indicate mean values for each sample tree.
Table 4. Correlation coefficient of basic density and compressive strength parallel to the grain for inner and outer woods.

\begin{tabular}{cccc}
\hline $\begin{array}{c}\text { Inner side } \\
\text { (position } \\
\text { from pith) }\end{array}$ & $\begin{array}{c}\text { Outer side } \\
\text { (position from } \\
\text { bark side) }\end{array}$ & $\begin{array}{c}\text { Correlation } \\
\text { coefficient } \\
\text { in BD }\end{array}$ & $\begin{array}{c}\text { Correlation } \\
\text { coefficient } \\
\text { in CS }\end{array}$ \\
\hline $2 \mathrm{~cm}$ & $2 \mathrm{~cm}$ & $0.452 \mathrm{~ns}$ & $0.496 \mathrm{~ns}$ \\
$4 \mathrm{~cm}$ & $4 \mathrm{~cm}$ & $0.449 \mathrm{~ns}$ & $0.650^{*}$ \\
$6 \mathrm{~cm}$ & $6 \mathrm{~cm}$ & $0.637^{*}$ & $0.812^{* *}$ \\
\hline
\end{tabular}

Note: number of sample $=10 ;{ }^{*}$, significance at $5 \%$ level; ${ }^{*}$, significance at $1 \%$ level; ns, no significance.

\section{Conclusions}

This study evaluated the relationship between the growth and wood properties of 54-year-old Agathis sp. planted in Indonesia. The mean stem diameter, pilodyn penetration, and SWV in the plot were $40.2 \pm 11.3 \mathrm{~cm}, 23.4$ $\pm 2.1 \mathrm{~cm}$, and $3.85 \pm 0.43 \mathrm{~km} / \mathrm{s}$, respectively. No significant correlation coefficient $(r=-0.327$, no significance at $5 \%$ level) was obtained between stem diameter and stresswave velocity. The mean $\mathrm{BD}$ and $\mathrm{CS}$ in the selected 10 trees were $0.42 \pm 0.03 \mathrm{~g} / \mathrm{cm}^{3}$ and $28.1 \pm 2.7 \mathrm{MPa}$, respectively. Significant differences in BD and CS of the 10 selected trees by ANOVA. Significant correlations were observed between BD and $C S$ at $6 \mathrm{~cm}$ from the pith and 6 $\mathrm{cm}$ from the bark, suggesting that the early selection of wood with high density and strength may be possible in Agathis sp. Thus, wood quality improvement could be achieved in Agathis sp. by the selection of trees with high density and strength in tree breeding programs.

\section{Acknowledgments}

The authors express their sincere thanks to Mr. Budi Prihanto, Manager of the Educational Forest, Bogor Agricultural University for providing the sample trees. This research was financially supported by the Utsunomiya University Exploratory Research for Young Scientists. 


\section{References}

Chauhan, C.C.; J.C.F Walker. 2006. Variation in Acoustic Velocity and Density with Age, and their Interrelationships in Radiata Pine. Forest Ecology and Management 229: 388-394.

Chudnoff, M. 1980. Tropical Timbers of the World. USDA Forest Service, Washington DC.

Ikeda, K.; T. Arima. 2000. Quality Evaluation of Standing Trees by a Stress-Wave Propagation Method and Its Application II, Evaluation of Sugi Stands an Application to Production of Sugi (Cryptomeria japonica D. Don) Structural Square Sawn Timber. Mokuzai Gakkaishi 46: 189-196.

Iki, T.; A. Tamura; N. Nishioka; M. Abe; K. lizuka. 2009. Longitudinal Changes of Basic Density and NonDestructive Quality Evaluation Using the Pilodyn in Todomatsu (Abies sachalinensis) Plus Tree Clones. Mokuzai Gakkaishi 55: 18-28.

Ishiguri, F.; J. Eizawa; Y. Saito; K. lizuka; S. Yokota; N. Yoshizawa. 2006. Comparison of Wood Properties of Hinoki (Chamaecyparis obtusa) Small Diameter Logs Collected from Different Tree Ages and Heights. Mokuzai Gakkaishi 52: 383-388.

Ishiguri, F.; R. Matsui; K. lizuka; S. Yokota; N. Yoshizawa. 2008. Prediction of the Mechanical Properties of Lumber by Stress-Wave Velocity and Pilodyn Penetration of 36-Year-Old Japanese Larch Trees. Holz Roh Werkst 66: 275-280.

Ishiguri, F.; I. Wahyudi; K. lizuka; S. Yokota; N. Yoshizawa. 2010. Radial Variation of Wood Property in Agathis sp. and Pinus insularis Growing at Plantation in Indonesia. Wood Research Journal 1(1): 1-6.

Kollman, F.F.P.; W.A. Côté. 1984. Principles of Wood Science and Technology, Vol 1: Solid Wood. Springer,
Berlin Heidelberg New York Tokyo.

Matsumoto, K.; F. Ishiguri; K. lizuka, S. Yokota; N. Yoshizawa. 2008. Evaluation of Bending and Compression Strength of Wood Using Fractometer. Wood Industry 63: 358-363.

Soerianegara, I.; R.H.M.J. Lemmens. 1994. Plant Resources of South-East Asia No 5(1): Timber Trees: Major Commercial Timbers. Prosea, Bogor.

Taylor, F.W. 1981. Rapid Determination of Southern Pine Specific Gravity with a Pilodyn Tester. Forest Science 27: 59-61.

Wood Technology Division and Forest Products Chemistry Division. 1974. The Properties of Tropical Woods (19): Studies on the Utilization of Ten Species from Kalimantan and New Guinea. Bulletin of the Government Forestry Experiment Station 262: 59-163.

Futoshi Ishiguri, Kazuko Makino, Jun Tanabe, Yuya Takashima, Kazuya lizuka, Shinso Yokota, and Nobuo Yoshizawa

Faculty of Agriculture, Utsunomiya University

Utsunomiya 321-8505, Japan

Tel : : +81-286495541

Fax : $+81-286495541$

E-mail : ishiguri@cc.utsunomiya-u.ac.jp

Imam Wahyudi

Faculty of Forestry, Bogor Agricultural University,

Bogor 16680, Indonesia

Tel : : +62-251-8621285

Fax : : +62-251-8621285

E-mail : imyudarw@yahoo.com 